\title{
Roland Deines
}

\section{Acts of God in History}

\section{Studies Towards Recovering a Theological Historiography Ed. by Christoph Ochs and Peter Watts}

[Handeln Gottes in der Geschichte. Studien zur Wiedergewinnung einer theologischen Geschichtsschreibung.]

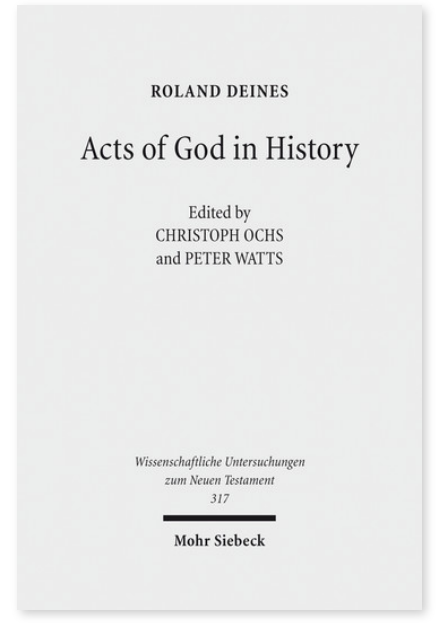

2013. XXIII, 502 Seiten. WUNT I 317

ISBN 978-3-16-152858-3

DOI 10.1628/978-3-16-152858-3

eBook PDF 189,00

ISBN 978-3-16-152181-2

Leinen $189,00 €$
Veröffentlicht auf Englisch.

Die 11 Aufsätze dieses Bandes sind von der Überzeugung getragen, dass Gott in der Geschichte handelt und dies in der biblischen Exegese methodisch ernst genommen werden muss. In historischen und methodologischen Überlegungen geht Roland Deines der Frage nach, wie Gott in der Geschichte erfahren wird und wie sich diese Erfahrung in den biblischen Texten niederschlägt. Der Bogen reicht von den Pharisäern bis zu Bar Kochba, und vom historischen Jesus bis zum Aposteldekret. Als methodische Beispiele werden die Jesusbücher von Martin Hengel und Josef Ratzinger (Papst Benedikt XVI) herangezogen. Roland Deines verfolgt mit diesen Studien das Ziel, Beiträge zu einer theologisch motivierten Historiographie zu liefern, die über die Wirklichkeit dieser Welt und ihrer Geschichte unter der Voraussetzung nachdenkt, dass der eine Gott, den die Heiligen Schriften der jüdisch-christlichen Tradition bezeugen, tatsächlich Schöpfer, Erhalter und Vollender dieser Welt und ihrer Geschichte ist.

Inhaltsübersicht

Introduction: God's Role in History as a Methodological Problem for Exegesis

Part One: Historical StudiesThe Social Profile of the Pharisees - Jesus the Galilean: Questioning the Function of Galilee in Recent Jesus Research - Jesus and the Jewish Traditions of His Time - The Apostolic Decree: Halakha for Gentile Christians or Christian Concession to Jewish Taboos?

Part Two: Responses to the God who Acts How Long? God's Revealed Schedule for Salvation and the Outbreak of the Bar Kokhba Revolt - Biblical Viewpoints on Repentance, Conversion, and Turning to God - The Term and Concept of Scripture

Part Three: Methodological Probings The Recognition of God's Acting in History in the Gospel of Matthew - Can the 'Real' Jesus be Identified with the Historical Jesus? Joseph Ratzinger's (Pope Benedict XVI) Challenge to Biblical Scholarship - Pre-existence, Incarnation and Messianic Self-understanding of Jesus in the Work of Martin Henge

Roland Deines Born 1961; 1997 PhD; 2003 Habilitation; until 2016 Professor of New Testament at the University of Nottingham; since 2017 Professor of Biblical Theology and Ancient Judaism at Internationale Hochschule Liebenzell.

Christoph Ochs Born 1977; PhD in Theology at the University of Nottingham, currently working as a Research Assistant in the Department of Theology and Religious Studies, University of Nottingham.

Peter Watts Born 1981; PhD candidate and Teaching Associate in Biblical Studies in the Department of Theology and Religious Studies, University of Nottingham.

Jetzt bestellen:

https://mohrsiebeck.com/buch/acts-of-god-in-history-9783161528583?no_cache=1

order@mohrsiebeck.com

Telefon: +49 (0)7071-923-17

Telefax: +49 (0)7071-51104 